\begin{tabular}{|c|c|c|}
\hline \multirow[t]{2}{*}{ BENTHAM OPEN } & $\begin{array}{c}\text { The Open Chemical Engineering } \\
\text { Journal }\end{array}$ & 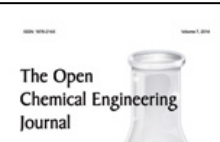 \\
\hline & Content list available at: www.benthamopen.com/TOCENGJ/ & \\
\hline
\end{tabular}

\title{
RETRACTION
}

\section{Retraction Notice: MOEA/D with Adaptive IWO for Synthesizing Phase-Only Reconfigurable Linear Arrays}

Yanyan Tan*, Shengtao Li and Xiaonan Fang

School of Information Science and Engineering, Shandong Normal University, Jinan 250014, China Shandong Provincial Key Laboratory for Novel Distributed Computer Software Technology, Shandong Normal University, Jinan 250014, China

\section{RETRACTION}

The Publisher and Editor have retracted this article [1] in accordance with good ethical practices. After a thorough investigations we believe that the peer review process was compromised. The article was published on-line on 21-10-2015.

\section{REFERENCE}

[1] Y. Tan, S. Li, and X. Fang, "MOEA/D with adaptive IWO for synthesizing phase-only reconfigurable linear arrays", Open. Chem. Eng. J., vol. 9, pp. 125-133, 2015.

(C) Tan et al.; Licensee Bentham Open.

This is an open access article licensed under the terms of the Creative Commons Attribution-Non-Commercial 4.0 International Public License (CC BY-NC 4.0) (https://creativecommons.org/licenses/by-nc/4.0/legalcode), which permits unrestricted, non-commercial use, distribution and reproduction in any medium, provided the work is properly cited.

\footnotetext{
* Address correspondence to this author at the 88 East Wenhua Road, Jinan, Shandong P. R. China; E-mail: yytan928@163.com
} 